Proc. Estonian Acad. Sci. Geol., 2000, 49, 1, 28-43

\title{
THE NEW TRILOBITE GENUS VALDARIOPS FROM THE HARJU SERIES (UPPER ORDOVICIAN) OF ESTONIA
}

\author{
Arvo RÕÕMUSOKS
}

Institute of Geology, University of Tartu, Vanemuise 46, 51014 Tartu, Estonia; geol@ut.ee

Received 13 October 1999, in revised form 15 December 1999

\begin{abstract}
The species Phacops (Chasmops) eichwaldi Schmidt, 1881 from the previous Lyckholm Stage, corresponding to the Nabala, Vormsi, and Pirgu stages, has been defined by Schmidt (1881, Mém. Acad. Imp. Sci. St.-Petersb., Sér. $7,30,1)$ in a very wide sense and is virtually a composite species. This species-group is here assigned to a new genus Valdariops, with the species $V$. eichwaldi (emended), V. aliquantulus sp. nov., V. angustus sp. nov., and V. kernuensis sp. nov. Two additional forms are figured as Valdariops sp. nov. A and Valdariops sp. nov. B. All these species have a stratigraphically limited range as guide fossils for different parts of the sequence of the Harju Series in the North Estonian Confacies Belt.
\end{abstract}

Key words: trilobites, Valdariops gen. nov., Ordovician, Estonia.

Schmidt (1881, p. 117) described Phacops (Chasmops) eichwaldi as a single representative of the subgenus occurring in the Lyckholm Stage. The Lyckholm Stage of Schmidt, with an average thickness of $80 \mathrm{~m}$ in northwestern Estonia, corresponds to the Nabala, Vormsi, and Pirgu stages in the current Estonian stratigraphical classification of the Harju Series (Jaanusson 1944; Männil 1958; Männil \& Meidla 1994). All specimens figured by Schmidt as eichwaldi have been found in the Vormsi Stage, except for a hypostoma (Schmidt 1881, pl. IV, fig. 4) found from the uppermost Pirgu Stage erratics in Schwarzen (nowadays Vardi) of the Rapla district, northern Estonia. Unfortunately, the generic affinity of this specimen is yet unknown; it may belong to any Toxochasmops. According to Schmidt (1881, p. $119 ; 1907$, p. 7), specimens of eichwaldi occurred in three exposures: Neuenhof in Harrien (nowadays Uuemõisa in the Harju district), Kirna (nowadays Kernu, Mõnuste, or Saunja), and Oddalem (Odulema). In these localities, as now generally known, the Nabala Stage (Saunja Formation) crops out. Besides, Schmidt mentioned the localities Schwarzen and Neuenhof bei 
Hapsal (nowadays Uuemõisa or Rannaküla near the town of Haapsalu), where also some specimens of eichwaldi have been found. In fact, there occur erratics from the upper beds of the Pirgu Stage (Adila Formation), derived from the northernmost side of the area, where this formation crops out. According to Schmidt, $P$. (C.) eichwaldi has been recognized also in the Porkuni Stage at Borkholm (Porkuni). However, the single cephalon available (figured here, Pl. II, fig. 8) came not from the Porkuni Stage, but from the Röa Member, topmost Pirgu Stage (Rõõmusoks 1991, pp. 30, 31). A pygidium found from the Adila Formation of the Pirgu Stage (figured here, Pl. II, figs. 9, 10) may be identifed as this, probably new species. I have previously treated Chasmops eichwaldi in Schmidt's wide sense (Rõõmusoks 1953).

My recent revision has proved that eichwaldi in Schmidt's concept constitutes a composite species, including six related forms (Chasmops eichwaldi speciesgroup; Rõõmusoks 1997, p. 237), which are here assigned to a new genus Valdariops. Besides, a form from the Vormsi Stage, strongly different from eichwaldi, included in this species by Schmidt (1881, pl. X, fig. 21), has recently been described as Toxochasmops (T.) vormsiensis sp. nov. (Rõõmusoks 1998, p. 186; pl. IV, figs. 1-10).

The first publication that dealt with Valdariops-like trilobites from the Ordovician outside northern Estonia is that of Wigand (1888, p. 53; pl. VII, fig. 4), who briefly described a cephalon as Phacops cf. eichwaldi Schmidt from the Macroura Limestone erratics in northern Germany, derived from the South Bothnian submarine Ordovician (see Jaanusson \& Ramsköld 1993, p. 744, text-fig. 1). According to Wigand, this specimen has comparatively small eyes and lacks L2. Subsequently, Pompecki (1890, p. 27; pl. I, figs. 21-23) has described in more detail a similar cephalon from the eastern Prussian erratics of the former Lyckholm Stage (probable Östersjö Limestone, German Ostsee-Kalk) as Phacops (Chasmops) eichwaldi. According to Pompecki, this cephalon is flat and lacks any tubercles or granulation on glabella. L2 is also missing and eyes are very small, positioned near the posterior part of the pleural region. The above two forms from the erratics could be assigned to Valdariops as a new species. Unfortunately, their exact stratigraphical position is unknown. If Wigand's specimen was really from the Macrourus Limestone (now Moldå Formation of Sweden, an equivalent of the upper Keila to Oandu stages of northern Estonia), then it is the earliest known representative of Valdariops.

In the Öijle Myr erratics from the Östersjö Limestone (probably partially an equivalent of the upper Pirgu Stage of Estonia; pers. comm. by V. Jaanusson 1991) in Gotland, also derived from the submarine South Bothnian area, occurs a small form which has been described and figured by Wiman (1901, p. 168; pl. V, fig. 1) as Chasmops eichwaldi. It is characterized by a narrow frontal glabellar lobe, well defined L2, and faint tuberculation on glabella. Therefore it is not conspecific with Valdariops eichwaldi but may rather be referred to Toxochasmops as sp. nov. 
Störmer (1945) described and figured a form from the upper part of the Tretaspis Shale (= Venstöp Formation, an equivalent of the Rakvere Stage of northern Estonia) in Hadeland, Norway. Nevertheless, this form differs from the true eichwaldi in having a shorter frontal glabellar lobe, relatively longer L2, and less high genal spines and larger eyes. Consequently, it is not a species of Valdariops but apparently of Toxochasmops.

Two different cephala from the Östersjö Limestone erratics (corresponding partially also to the Rakvere and Nabala stages of the Estonian sequence) of northern Germany have been figured by Haller (1973, pl. XVII, figs. 1a-c and 2ac) as Chasmops eichwaldi. They differ from the lectotype of eichwaldi in having a less subparabolic, shorter, and narrower frontal glabellar lobe, covered by fine tuberculation, more or less defined L2 and larger eyes. These cephalons evidently belong to two different new species, perhaps of the genus Toxochasmops.

To sum up: all specimens, described and figured up to now by several authors outside Estonia as eichwaldi, are not conspecific with the lectotype as treated below.

The figured specimens are housed in the Museum of Geology, University of Tartu (prefixed TUG), Estonian Museum of Natural History, Tallinn (ELM g), Swedish Museum of Natural History, Stockholm (RM Ar), and Museum of Paleontology and Stratigraphy, University of St. Petersburg (PSM).

\section{Family PTERYGOMETOPIDAE Reed, 1905}

\section{Subfamily CHASMOPINAE Pillet, 1954}

Genus Valdariops gen. nov.

Derivation of name. In memory of late Professor Valdar Jaanusson, Estonian palaeontologist and stratigrapher.

Type species. Phacops (Chasmops) eichwaldi Schmidt, 1881 (revised here) from the Vormsi Stage (corresponding to the upper Pleurograptus linearis Zone) of northern Estonia.

Other species. Valdariops aliquantulus sp. nov., $V$.angustus sp. nov., $V$. kernuensis sp. nov. Two additional species figured here as Valdariops sp. nov. A (Pl. I, fig. 8) and Valdariops sp. nov. B (Pl. II, figs. 8-10).

Diagnosis. Cephalon normally subparabolic in outline. Cephalic border slightly arched from the middle in anterior view. Frontal glabellar lobe broad, on average $60 \%$ of cephalic width. Preglabellar field very narrow, ridge-like, bordering almost the whole width of frontal glabellar lobe. Anterior branch of facial suture runs in anterior border furrow. Genal regions usually conspicuously narrow. Genal spines long, anteriorly moderately high, slightly convergent posteriorly. L2 absent. Lateral border furrow weakly defined; posterior border furrow distinct but short. Eyes short, 24-27\% of cephalic length, situated near glabella and posterior 
border furrow. Glabella evidently covered by ultra-fine granulation; no tubercles. Thorax comparatively narrow, with rachis which is slightly broader to equal with pleural regions. Pygidium roughly triangular, usually flat, short, and with rachis tapering remarkably at the end. Pleural furrows laterally slightly inclined backwards.

Discussion. This new genus most likely evolved from the subgenus T. (Toxochasmops) which includes a small, rather Valdariops-like species T. (T.) inge Rõõmusoks, 1953 redescribed by the author (Rõõmusoks 1998) from the Oandu Stage, Hirmuse Formation (Dicranograptus clingani Zone). As compared to $T$. (Toxochasmops), the species referred to Valdariops have a lower, more subparabolic, and narrower cephalon. The frontal glabellar lobe comprises about $29-60 \%$ of cephalic width. L2 is missing. The sculpture consists of very fine dense granulation without tubercles. The pygidium is shorter, flatter, with weakly developed hindmost pleural ribs which are not parallel to the rachis as in T. (Toxochasmops). The species of T. (Schmidtops) Rõõmusoks, 1998 can be distinguished from the species of Valdariops by a considerably larger, broader, and usually more convex cephalon with the strongly arched cephalic anterior border, by having L2, and by the position of eyes farther from L3. The thoracic rachis is narrower than pleural areas; the pygidium is longer, higher, and more convex than in Valdariops.

The other genera of Chasmopinae, such as Chasmops M'Coy, 1849; Scopelochasmops McNamara, 1980a; Bolbochasmops McNamara, 1980a; Rollmops McNamara, 1980a; and Oculichasmops Rõõmusoks, 1986 are so different from Valdariops that a detailed discussion of the distinguishing features is here not necessary.

Occurrence. Nabala and Vormsi stages (Pleurograptus linearis Zone) and Pirgu Stage (Dicellograptus anceps Zone). The earliest representative of Valdariops recorded in northern Estonia is figured here as Valdariops sp. nov. A from the Nabala Stage, Paekna Formation (Pl. I, fig. 8), the latest form as Valdariops sp. nov. B from the uppermost beds of the Pirgu Stage (PI. II, figs. 8-10). Besides, any new species of Valdariops may occur also in erratics of the Moldå Limestone (?) and Östersjö Limestone in northern Germany, derived from the South Bothnian submarine Ordovician sequence.

Valdariops eichwaldi (Schmidt, 1881)

Plate I, figures 1-7

1860 Chasmops odini Eichwald, p. 1429 (pars).

1861 Chasmops odini Eichwald, pl. XXXI, fig. 32.

1881 Phacops (Chasmops) eichwaldi Schmidt, p. 117 (pars), pl. V, figs. 8a-c, 9, 16 (non fig. $10=$ Valdariops angustus sp. nov.).

1907 Phacops (Chasmops) eichwaldi Schmidt, p. 7 (pars). 
1937 Chasmops eichwaldi (Schmidt); Öpik, p. 85, pl. IX, fig. 1.

1953 Chasmops eichwaldi (Schmidt); Rõõmusoks, p. 412 (pars, range).

1979 Toxochasmops eichwaldi (Schmidt); McNamara, p. 79 (pars, named only, range).

1980a Toxochasmops eichwaldi (Schmidt); McNamara, p. 68 (pars, named only, range).

1980b Toxochasmops eichwaldi (Schmidt); McNamara (pars) pp. 64, 65, fig. 2A-C.

Lectotype. Selected by Öpik (1937, p. 85); figured by Schmidt (1881, pl. V, figs. 8a-c); refigured here in Pl. I, figs. 1-4; PSM 1/2733; Eichwald's collection; Hiiumaa Island, western Estonia (exact locality unknown); erratic from the Vormsi Stage, Kõrgessaare Formation (upper Pleurograptus linearis Zone). An early illustration of this specimen by Eichwald (1861) was inadequate, featuring pygidium which was actually missing.

Other material. One glabella (figured by Schmidt 1881, pl. V, fig. 9; Öpik 1937, pl. IX, fig. 1), one incomplete cephalon, and two incomplete isolated pygidia (Pl. I, figs. 5-7). Thus, V. eichwaldi is a rare species.

Diagnosis. Genal regions comparatively high. Frontal glabellar lobe noticeably flat anteriorly, its width about $63 \%$ of cephalic width. L3 elongate, narrow. Eyes small, short-conical, comprising about $22-24 \%$ of cephalic length. Their anterior ends reach about mid-length of L3. Pygidial pleural areas anteriorly broader than rachis; pleural furrows turn laterally aslant backwards.

Description. Cephalon moderately convex in transverse section; its length (sag.) forms about $68 \%$ of the width. Genal region relatively high. Genal spines long, moderately high anteriorly and slightly convergent posteriorly. Frontal glabellar lobe broad, transversely narrowly subparabolic in outline. L3 narrowly triangular, elongate; L2 is lacking; L1 forms a narrow ring slightly narrower and shorter than occipital ring. Dorsal furrows very narrow and shallow. Preglabellar field ridgelike, about as broad as the frontal glabellar lobe. Anterior cephalic border and preglabellar furrows well defined. Posterior border furrow deep; lateral border

\section{Explanation of Plate I}

Figs. 1-7. Valdariops eichwaldi (Schmidt, 1881); Vormsi Stage, Kõrgessaare Formation. 1-4, PSM $1 / 2733$, lectotype; Hiiumaa Island, northwestern Estonia, from an erratic boulder, coll. by E. Eichwald: 1, dorsal view of cephalon with anterior part of thorax $(\times 1.6) ; 2-4$, cephalic anterior ( $\times 1.7)$, ventral $(\times 1)$, and left lateral ( $\times 1.6)$ views. 5, 6, TUG 108-7, Väljataguse, coll. by L. Sarv \& V. Karise, 1953; dorsal $(\times 1.8)$ and right lateral $(\times 2)$ views of pygidial internal mould. 7, TUG 990-41, Lyckholm, coll. by author, 1965; dorsal view of pygidial internal mould $(\times 2)$.

Fig. 8. Valdariops sp. nov. A; TUG 76-5; Nabala Stage, Paekna Formation; uppermost Dicranograptus clingani Zone; Narva River bank at Permisküla or Kokolok, northeastern Estonia, coll. by T. Heinrichson, 1933; dorsal view of incomplete cephalon $(\times 2)$. 
PLATE I
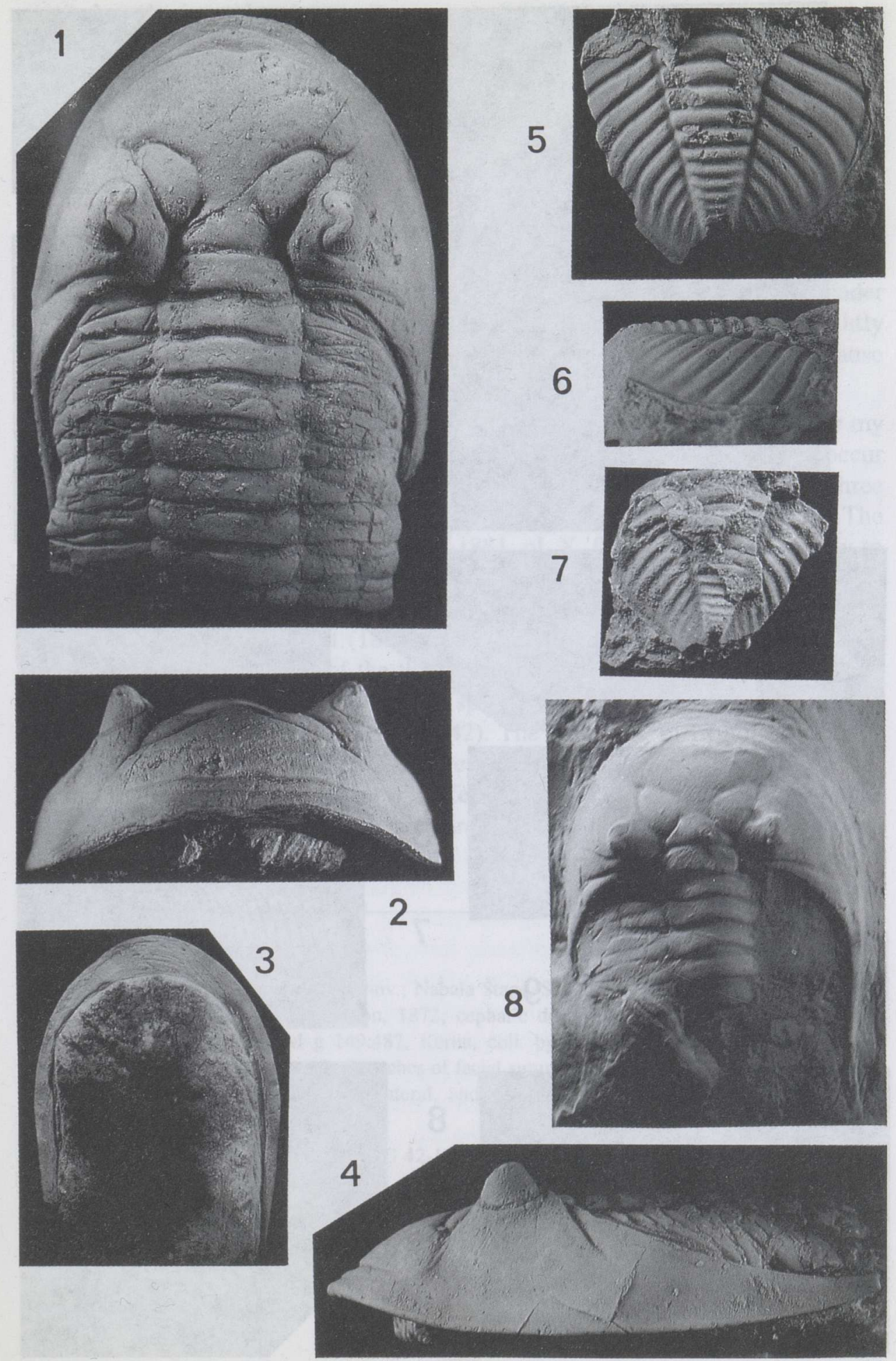
PLATE II
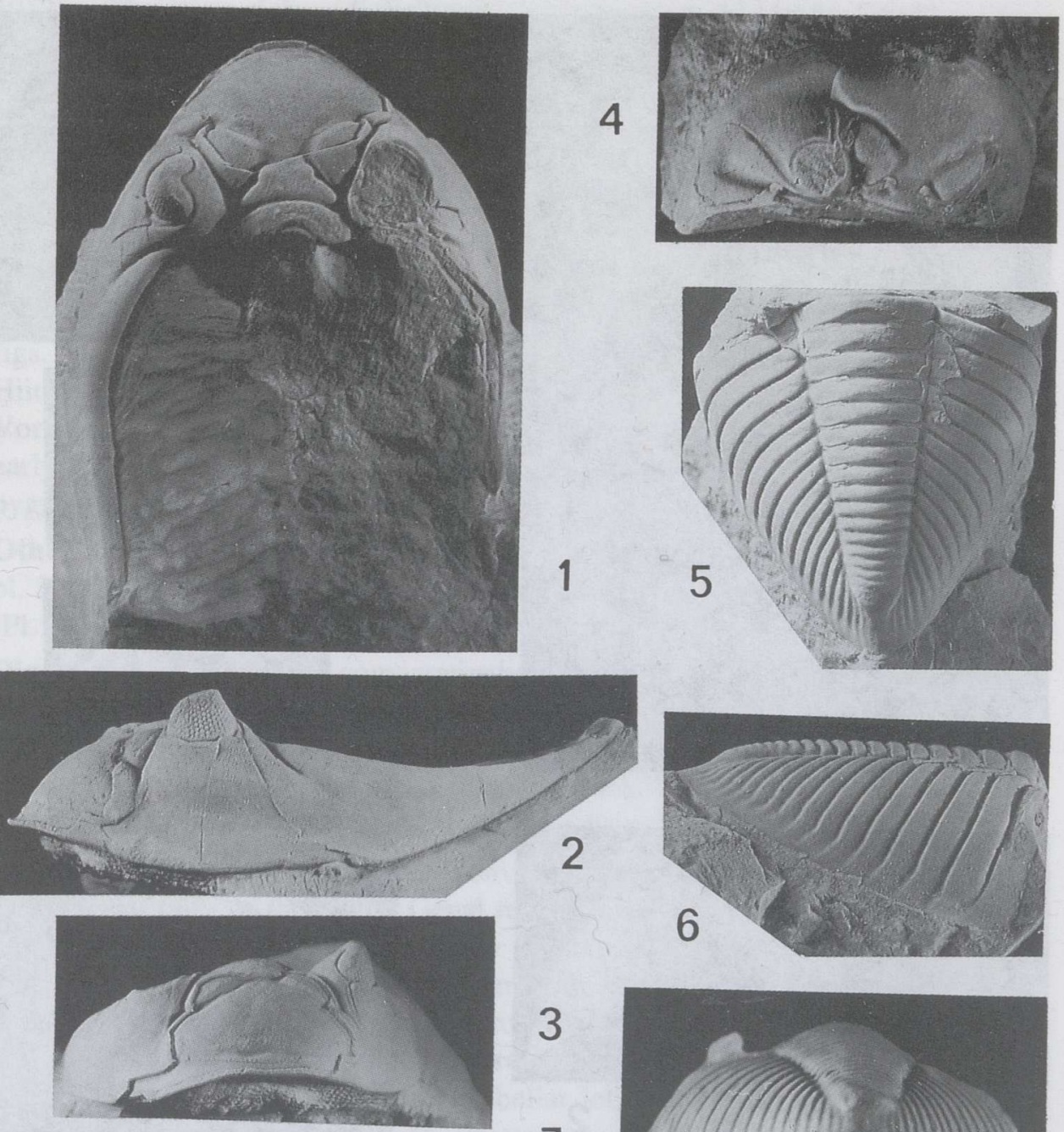

1
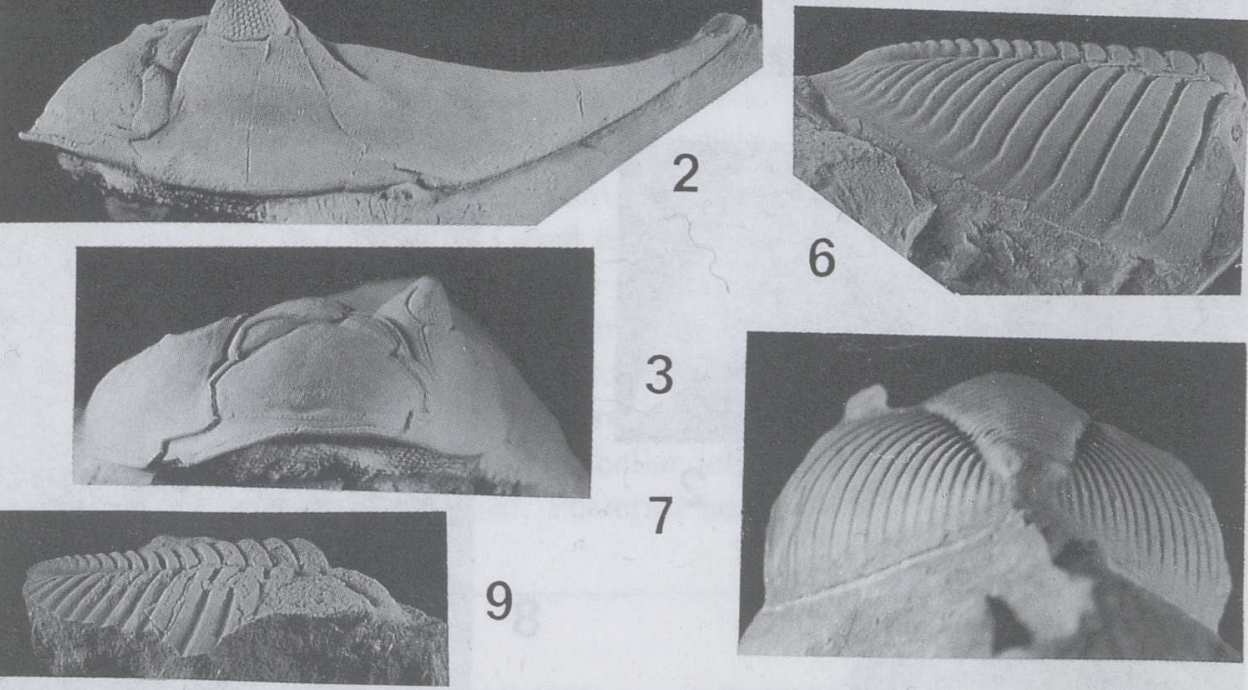

9
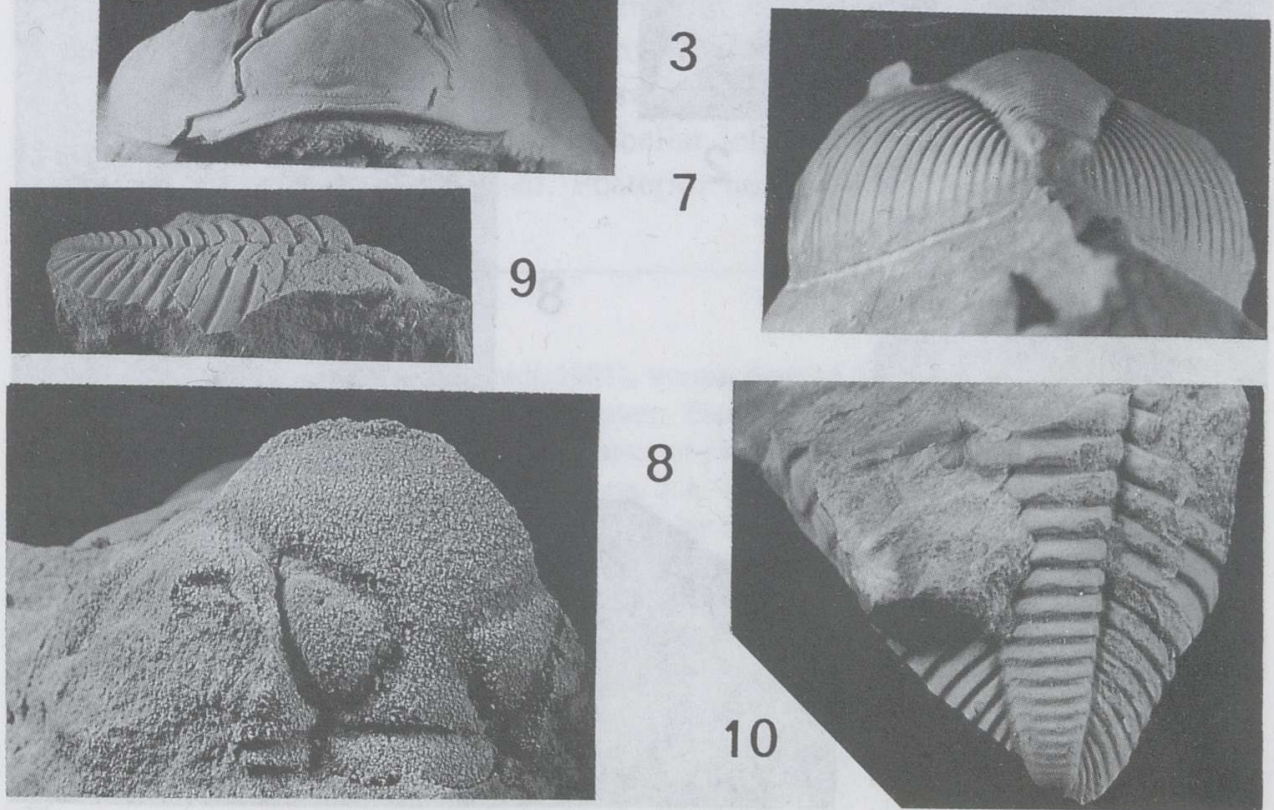
furrow rather weak. Eyes small, about $22-24 \%$ of the cephalic length, shortconical and situated subcentrally in genal region. Palpebral lobe stretches somewhat higher at the surface of the glabella. Anterior branch of the facial suture extends in front of the eye almost directly to the lateral corner of the frontal glabellar lobe, running after that forwards in the anterior border furrow. Posterior branch of the facial suture weakly defined in lectotype. Cephalic doublure broad anteriorly, medially gently concave, changing ridge-like laterally. At least the anterior border of the cephalon is covered by very fine dense granulation. Thorax of the lectotype is preserved with nine segments (Pl. I, fig. 1). The rachis is slightly broader than pleural areas. Rachial ribs noticeably long, weakly convex (sag.). Pygidium fairly flat. Pleural areas somewhat broader anteriorly than rachis and with broad foremost ribs; pleural furrows slightly turned aslant backwards distally. Number of pleural furrows unknown, because two pygidia available are incomplete, without hindmost part.

Discussion. Examination of chasmopine trilobites from the Vormsi Stage for my recent paper (1998) disclosed that three evidently separate pygidial types occur there. Already Schmidt (1881, pl. V, figs. 10, 16; pl. X, fig. 21) figured three different isolated pygidium types, all of which he included to eichwaldi. The largest and broadest pygidium (Schmidt 1881, pl. X, fig. 21) belongs actually to T. (Toxochasmops) vormsiensis Rõõmusoks, 1998. This species is quite common in the Lower Vormsi Stage. The second pygidium type is represented by a specimen figured by Schmidt (1881, pl. V, fig. 10) and by two specimens with the preserved posterior part of the thorax, figured here (Pl. III, figs. 3, 6). They are identified as Valdariops angustus sp. nov. based on comparison with a complete enrolled specimen (TUG 990-42). The third type of pygidium belongs to the true eichwaldi (Pl. I, figs. 5-7 here; see also Schmidt 1881, pl. V, fig. 16, but this figure is not quite adequate). Differences between eichwaldi and a similar contemporary species angustus sp. nov. are discussed below.

\section{Explanation of Plate II}

Figs. 1-7. Valdariops aliquantulus sp. nov.; Nabala Stage, Saunja Formation. 1-3, RM Ar 34606, holotype; Kernu, coll. by G. Linnarsson, 1872; cephalic dorsal $(\times 2.2)$, left lateral $(\times 2.1)$, and anterior ( $\times 1.7)$ views. 4, ELM g 149:487, Kernu, coll. by F. Schmidt; oblique dorsal view of cephalic internal mould, showing the branches of facial sutures $(\times 2)$. 5-7, TUG 81-6; Taaldevälja, coll. by I. Mitnits, 1948; dorsal, right lateral, and posterior views of pygidial internal mould (all $\times 2$ ).

Figs. 8-10. Valdariops sp. nov. B; 8, TUG 42-110; uppermost Pirgu Stage, Ärina Formation, Röa Member; (Dicellograptus anceps Zone); northern Estonia, Kuru, coll. by F. Schmidt; dorsal cephalic view of incomplete internal mould in dolomitized limestone $(\times 2) .9,10$, TUG 80-207; uppermost Pirgu Stage, Adila Formation, Vormsi Island, Hosholm coast, coll. by V. Jaanusson, S. Kiin, and R. Männil, 1939; right lateral $(\times 1.6)$ and dorsal $(\times 2)$ views of incomplete pygidial internal mould. 
Occurrence. Vormsi Stage, Kõrgessaare Formation (Pleurograptus linearis Zone); exposures of Paopa and Kõrgessaare on Hiiumaa Island, Lyckholm and Väljataguse on the mainland of northwestern Estonia.

Valdariops aliquantulus sp. nov.

Plate II, figures 1-7

1881 Phacops (Chasmops) eichwaldi Schmidt, p. 117 (pars).

Derivation of name. Latin aliquantulus, smallish, alluding to relatively small size of specimens available.

Holotype. Almost complete cephalon with partially exfoliated frontal glabellar lobe (Pl. II, figs. 1-3), RM Ar 34606, Kernu or Mõnuste, northern Estonia. Nabala Stage, uppermost Saunja Formation (upper Pleurograptus linearis Zone), coll. by G. Linnarsson, 1872.

Other material. Three incomplete cephalic internal moulds and seven incomplete pygidial internal moulds.

Diagnosis. Cephalon conspicuous for its shortness; genal regions fairly confined. Genal spines long, anteriorly relatively high, tapering off from mid-length. Frontal glabellar lobe width about $52 \%$ of cephalic width. Anterior border and preglabellar field very narrow. Eyes long, about $27 \%$ of cephalic length, positioned anteriorly fully near the dorsal furrow. Pygidium elongately triangular, relatively high. Pleural areas with at least 15 pleural furrows anteriorly as wide as rachis.

Description. Cephalon broadly subparabolic in outline. Genal regions fairly high and narrow. Frontal glabellar lobe transversely moderately convex; anterior slope steep. L3 moderately large, bluntly triangular. Dorsal furrows steep. Occipital ring narrow, about $13 \%$ of the cephalic length. Outer portion of the posterior branch of the facial suture converges posteriorly with the posterior border furrow. Preglabellar furrow weakly defined. Posterior border furrow short, weakly developed. Genal spines rise slightly in the hindmost part. Lateral border furrow broad, but weak. Eyes high, narrowly-conical, as long as L3. Hypostoma and thorax unknown. Pygidium relatively high, elongately triangular in outline and convex. Pygidial rachis relatively narrow. Anterior pleural ribs noticeably broader than the hindmost ones, which are almost parallel to the rachis. Pleural furrows straight, turning laterally slightly backwards.

Discussion. $V$. aliquantulus is the smallest species known of the genus. It differs from $V$. eichwaldi and also contemporary V. kernuensis sp. nov. in having a relatively smaller and shorter glabella which is suboval in outline, smaller eyes, more elongate, convex and higher pygidium, relatively higher, shorter genal regions and longer, fairly pointed genal spines. 
Occurrence. Nabala Stage, Saunja Formation; exposures of Kernu, Odulema, Kohatu, and Taaldevälja on the mainland of Estonia, Saxby coast (erratic) on Vormsi Island.

\section{Valdariops angustus sp. nov. \\ Plate III, figures $1-8$}

1881 Phacops (Chasmops) eichwaldi Schmidt, p. 117 (pars), plate V, fig. 10.

Derivation of name. Latin angustus, narrow, alluding to the conspicuously narrow exoskeleton.

Holotype. Incomplete internal mould of cephalon (Pl. III, figs. 1, 2); ELM g 149:486, from the Vormsi Stage, basal beds of the Kõrgessaare Formation (upper Pleurograptus linearis Zone), Kernu quarry, northern Estonia; coll. by F. Schmidt and labelled by him as Chasmops eichwaldi.

Other material. One complete, but not well preserved enrolled specimen, two specimens with partly preserved thorax and pygidium (Pl. III, figs. 3, 5, 6), six more or less broken cephalic internal moulds (one with internal mould of hypostoma; Pl. III, fig. 8).

Diagnosis. A species of medium size for genus. Cephalic genal regions narrow, relatively low. Frontal glabellar lobe narrowly transversely suboval, low and short; its width $57-60 \%$ of cephalic width. L3 comparatively narrow, elongate. Eyes large, 25-27\% of cephalic length, situated near dorsal furrow, reaching to anterior one-third of length (exsag.) of L3. Thorax noticeably narrow; width of rachis about equal to width of pleural areas. Pygidial pleurae with evenly narrow ribs. There are ten to eleven pleural furrows which are almost upright laterally.

Description and discussion. $V$. angustus shows a considerable similarity with contemporary V. eichwaldi only. The cephalon is narrower than in eichwaldi; the maximum known width across genal spines is about $30 \mathrm{~mm}$. Cephalic length (sag.) is $67 \%$ of the cephalic width. The genal region is evidently lower and the frontal glabellar lobe is more convex in anterior view than in eichwaldi. The anterior border is narrower by half than in eichwaldi. Eyes are lower but relatively longer, almost as long as L3. The lateral border furrow is more defined; the posterior border furrow is shorter and broader than in eichwaldi. Pleural areas of thorax turn steeply downwards. Pygidium is relatively flat, short, narrowly triangular in outline; width of pleural areas is smaller than in eichwaldi. Pleural furrows run nearly vertical to the lateral border of the pygidium, whereas in eichwaldi they turn obliquely backwards. Among species of Valdariops hypostoma is known in angustus only. It resembles hypostomata of the species of Toxochasmops (Schmidtops) figured in Rõõmusoks (1998, pl. VII, figs. 8, 13; pl. VIII, fig. 13), but not hypostoma of $T$. (T.) wesenbergensis figured here 
(Pl. III, fig. 9) for comparison. Lateral borders are straight, converging moderately backwards. The median body is flat. The maculae are well defined. The anterior wings are relative long, transversally directed. The posterior furrow is distinct.

Occurrence. Vormsi Stage, mostly in lower beds of the Kõrgessaare Formation; exposures on Vormsi Island (Saxby coast and others) and on the mainland of northern Estonia (Aulepa, Turvaste, Mõnuste, and Kohila).

\section{Valdariops kernuensis sp. nov. \\ Plate IV, figures 1-9}

1881 Phacops (Chasmops) eichwaldi Schmidt, p. 117 (pars).

Derivation of name. From Kernu, a settlement in the Harju district of northern Estonia, near the localities of the Saunja Formation.

Holotype. Incomplete cephalon (Pl. IV, figs. 8, 9), RM Ar 34608, from the Nabala Stage, Saunja Formation, Kernu, coll. by G. Linnarsson, 1872.

Other material. Six incomplete cephalons and nine incomplete pygidia.

Diagnosis. Cephalon usually low, with narrow genal regions; anterior border slightly risen up medially. Anterior border and preglabellar field of almost equal width. Frontal glabellar lobe comparatively flat in the middle. L3 relative large, inflated, broadly bluntly triangular. Eyes large, comprising about $27-32 \%$ of cephalic length, positioned in the middle of gena and reaching to anterior onethird of the length (exsag.) of L3. Pygidial pleurae with at least ten to eleven pleural furrows, which laterally turn slightly backwards.

\section{Explanation of Plate III}

Figs. 1-8. Valdariops angustus sp. nov.; Vormsi Stage, Kõrgessaare Formation (mostly in lowermost beds), northwestern Estonia. 1, 2, ELM g 149:486, holotype; Kernu, coll. by F. Schmidt; dorsal $(\times 1.8)$ and anterior $(\times 2)$ views of incomplete cephalic internal mould. 3, TUG 2-324, Kohila, old collection; right lateral view of pygidial internal mould with part of thorax $(x 1.6)$. 4, ELM g 149:498, Turvaste, coll. by F. Schmidt; oblique left view of incomplete cephalic internal mould showing genal spine $(\times 1.8)$. 5, 6, TUG 80-209, Vormsi Island, Saxby coast, coll. by V. Jaanusson, S. Kiin, and R. Männil, 1939; right lateral view of pygidial internal mould with part of thorax $(\times 1.6)$ and dorsal view $(\times 2)$. 7, ELM g 149:11, Aulepa, coll. by F. Schmidt; left lateral view of cephalic internal mould $(\times 2)$. 8, TUG 79-128, Vormsi Stage, Kõrgessaare Formation, Vormsi Island, Saxby coast, coll. by V. Jaanusson, 1939; internal mould of hypostoma $(\times 2)$.

Fig. 9. (T.) Toxochasmops wesenbergensis (Schmidt); TUG 990-15, Rakvere Stage, town of Rakvere, coll. by author, 1942; hypostoma ( $\times 2)$. 

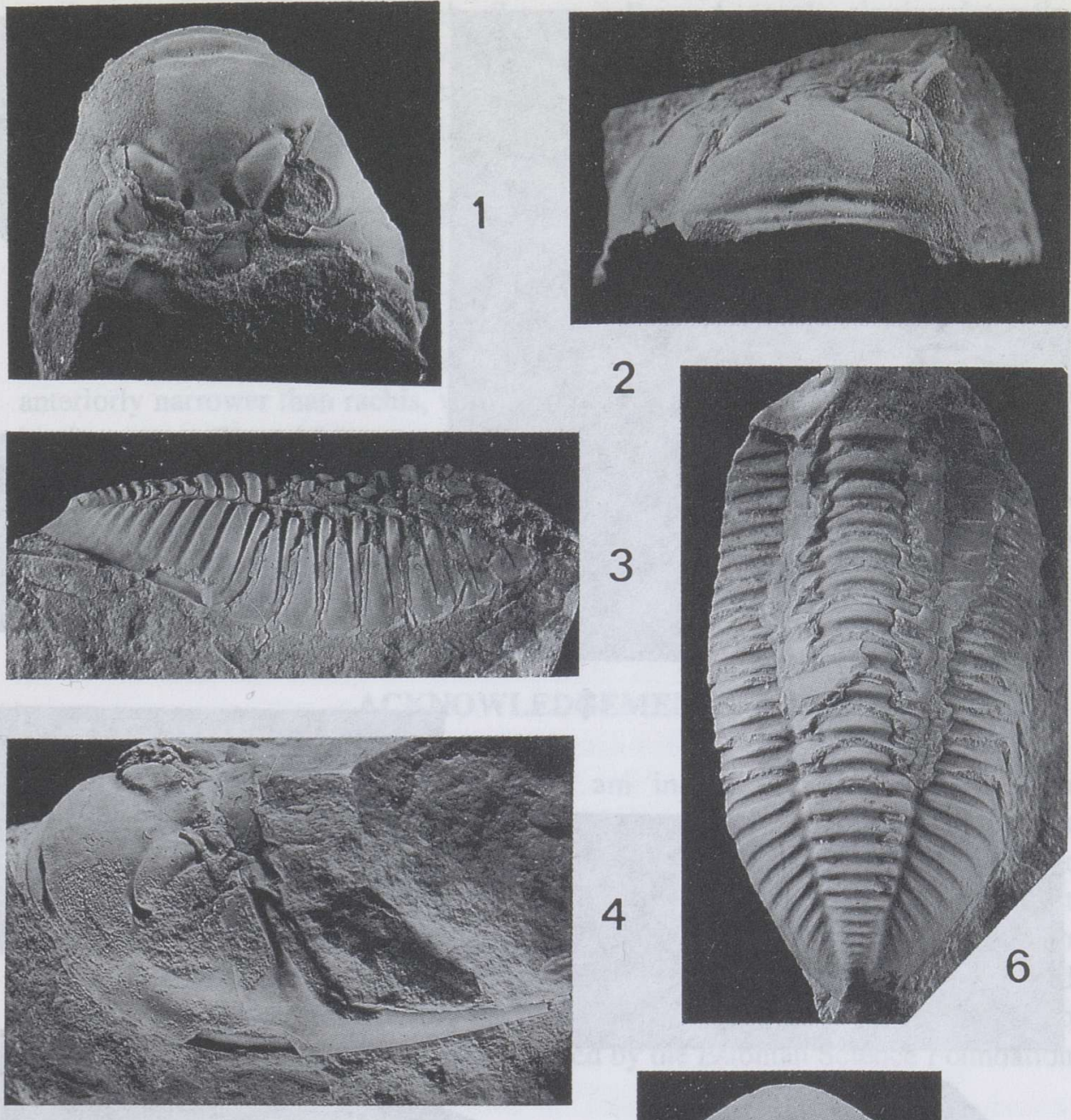

4
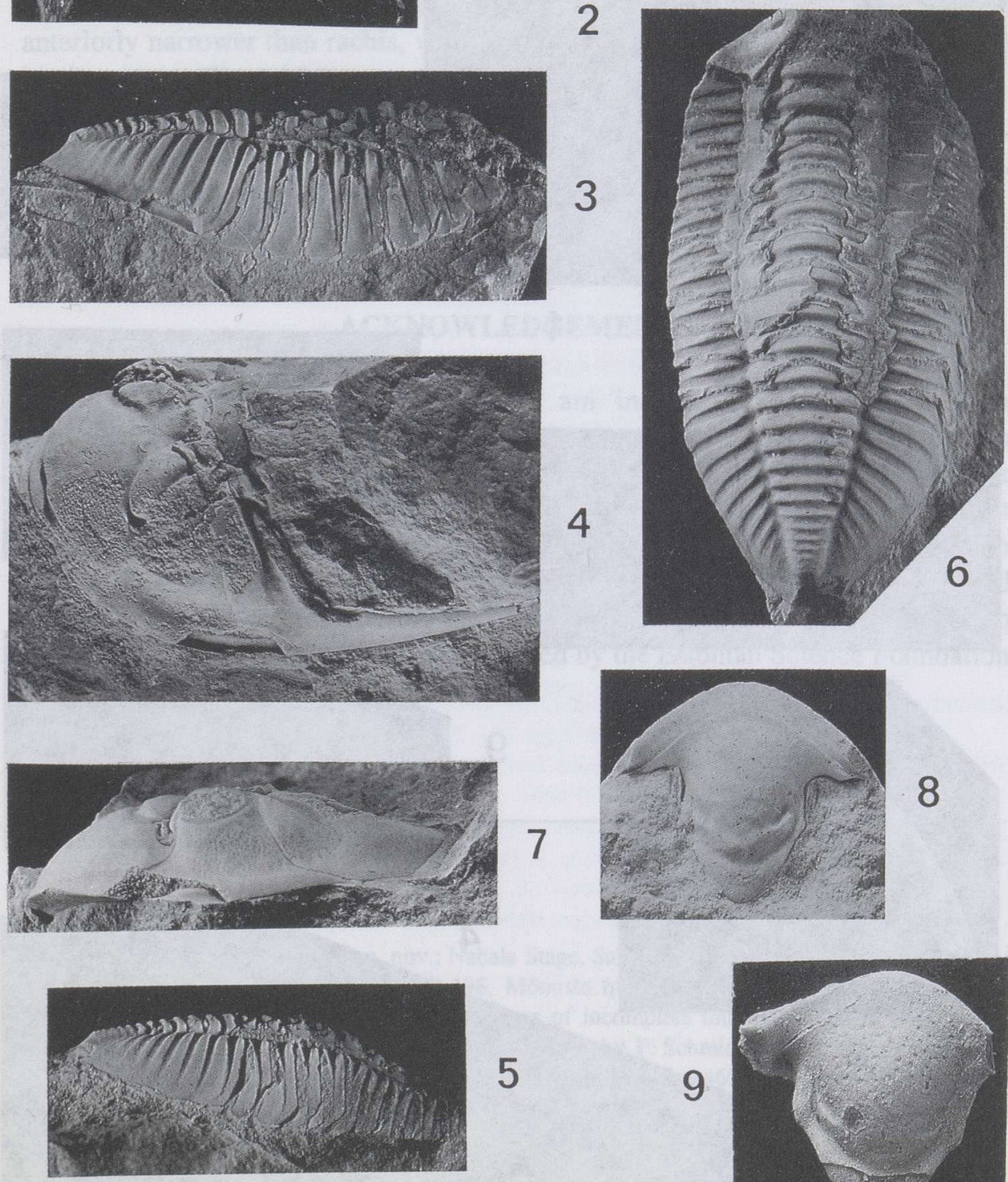

5

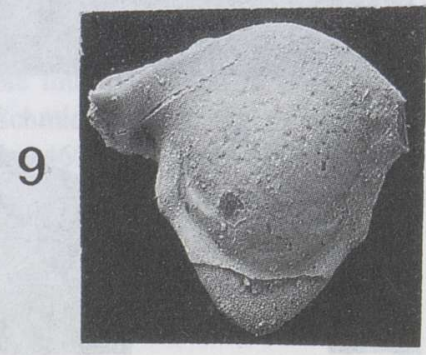




\section{PLATE IV}
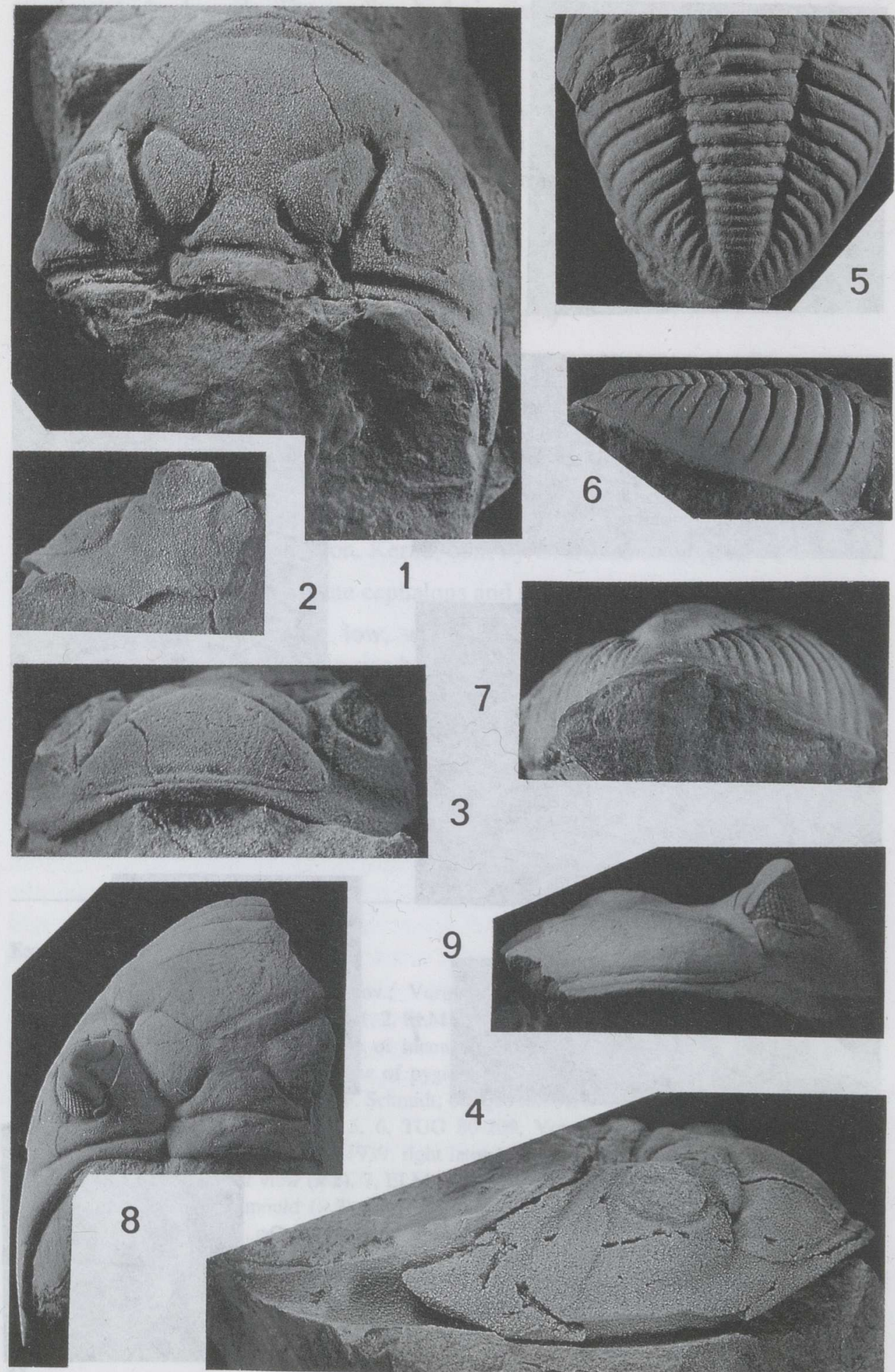

3
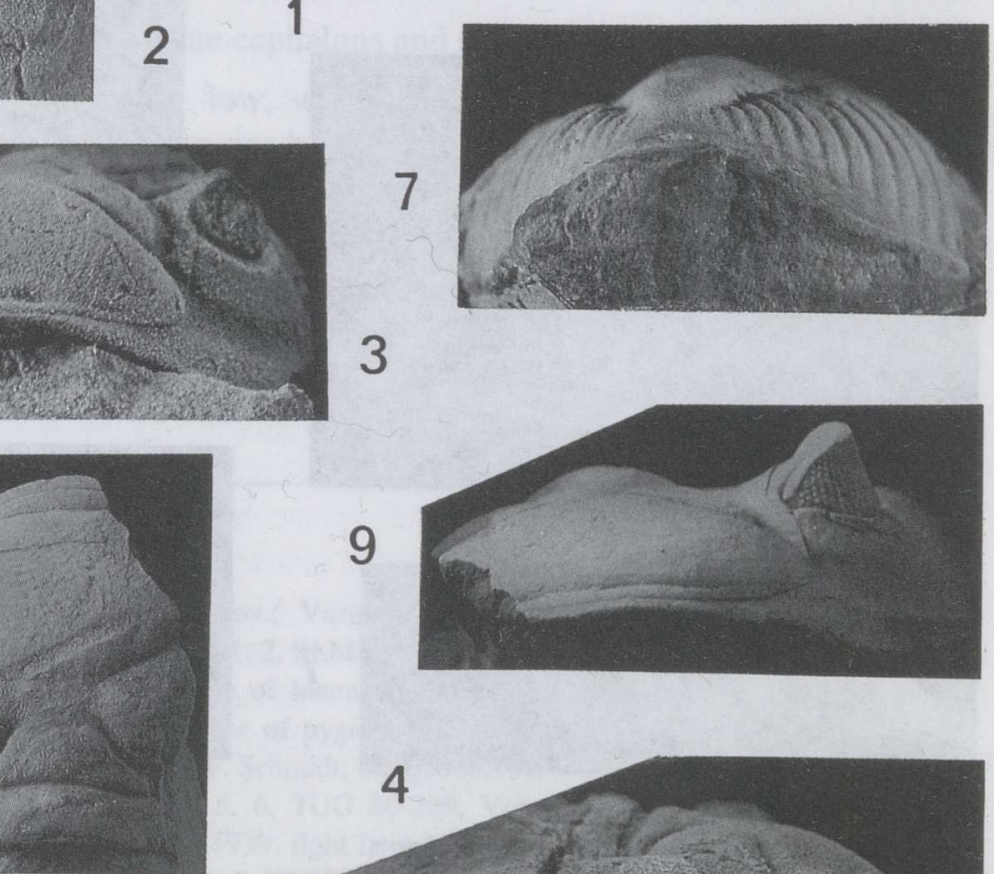

4

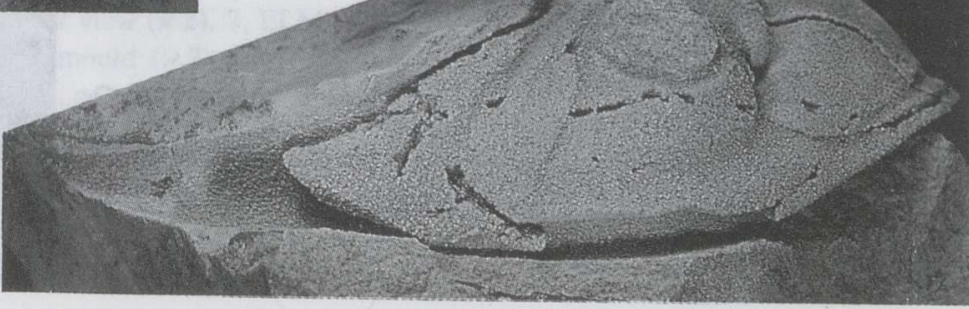


Description and discussion. Cephalon, unlike in other species, is almost semicircular in outline, relatively flat medially and steeply sloping laterally. Anterior margin slightly broadly arched. Genal regions comparatively confined laterally. Preglabellar furrow distinct medially. Frontal glabellar lobe relatively short; width about $47-60 \%$ of the cephalic width. Lateral border furrow broad, well defined. Eyes about as long as L3, broadly conical, weakly inclined forward, and positioned laterally of the gena. Genal spines not long but relatively high anteriorly. Dorsal furrows well defined, deep, and straight. Posterior border furrow deep, long, and narrow. Doublure narrower than in eichwaldi, almost flat medially. Hypostoma and thorax unknown. Pygidium is broadly triangular, more convex, and with the rachis anteriorly broader than in eichwaldi. Pleural areas anteriorly narrower than rachis, with noticeably broader anterior ribs than on the hindmost part. Pleural furrows turn laterally slightly backwards distally.

Occurrence. Nabala Stage, Saunja Formation (Pleurograptus linearis Zone), northern Estonia; exposures of Aulepa, Kernu, Mõnuste, Odulema, and Kohatu, and an outcrop in the town of Tapa.

\section{ACKNOWLEDGEMENTS}

For the loan of some specimens I am indebted to late V. Jaanusson (Naturhistoriska Riksmuseet, Sektionen för paleozoologi, Stockholm), D. L. Bruton (Paleontologisk Museum, Oslo), L. Holmer (Uppsala University), and T. Lodjak (Estonian Museum of Natural History, Tallinn). For the opportunity to work at Naturhistoriska Riksmuseet, J. Bergström is gratefully acknowledged. With thanks I remember stimulating discussions with V. Jaanusson. I. Puura and M. Rubel are thanked for revising the manuscript. This study is a contribution to the IGCP Project 410 and has been supported by the Estonian Science Foundation (grant No. 3011).

\section{Explanation of Plate IV}

Figs. 1-9. Valdariops kernuensis sp. nov.; Nabala Stage, Saunja Formation; Pleurograptus linearis Zone, northern Estonia. 1-4, TUG 1003-196, Mõnuste quarry, coll. by author, 1962; cephalic dorsal, left lateral, anterior, and right lateral views of incomplete internal mould in dolomitized limestone (all $\times 2$ ); 5-7, ELM g 149:10, Aulepa, coll. by F. Schmidt; dorsal, right lateral and posterior views of pygidial internal mould (all $\times 2$ ). 8, 9, RM Ar 34608, holotype; Nabala Stage, Saunja Formation, northern Estonia. Kernu, coll. by G. Linnarsson, 1872; dorsal and anterior views of incomplete cephalon (both $\times 2$ ). 


\section{REFERENCES}

Eichwald, E. 1860. Lethaea Rossica ou Paléontologie de la Russie. Vol. I. Seconde Section de l'ancienne Période. Stuttgart.

Eichwald, E. 1861. Atlas' $k^{\prime}$ paleontologii Rossii. Drevnij period' $i$ fauna grauvakkovoj, gornoizvestkovoj i m"distoslantsevatoj formatsij Rossii. St. Petersburg (in Russian).

Haller, J. 1973. Die ordovizische Trilobitengattung Chasmops aus balto-skandischen Geschieben. Paläont. Abh., Abt. A, 4, 723-768.

Jaanusson, V. 1944. Übersicht der Stratigraphie des Lyckholm - Komplexstufe. Bull. Comm. Geol. Finlande, 132, 92-100.

Jaanusson, V. \& Ramsköld, L. 1993. Pterygometopine trilobites from the Ordovician of Baltoscandia. Palaeontology, 36, 743-769.

McNamara, K. J. 1979. Trilobites from the Coniston Limestone Group (Ashgill Series) of the Lake District, England. Palaeontology, 22, 53-92.

McNamara, K. J. 1980a. Taxonomy and distribution of chasmopine trilobites. Geol. Mag., 117, 65-80.

McNamara, K. J. 1980b. Evolutionary trends and their functional significance in chasmopine trilobites. Lethaia, 13, 61-78.

Männil, R. 1958. Zur Stratigraphie der Oberordovizischen Nabala-Stufe $\left(\mathrm{F}_{\mathrm{I}} \mathrm{a}\right)$ in Estland. ENSV Tead. Akad. Geol. Inst. Uurimused, II, 3-17 (in Russian).

Männil, R. \& Meidla, T. 1994. The Ordovician System of the East European Platform (Estonia, Latvia, Lithuania, Byelorussia, parts of Russia, the Ukraine and Moldova). In The Ordovician System of the East European Platform and Tuva (Southeastern Russia), A (Webby, B. D., Ross, R. J. Jr. \& Zhen, Y. Y., eds.). IUGS Publication, 28, 1-52.

Öpik, A. 1937. Trilobiten aus Estland. Acta Comment. Univ. Tartuensis, 32.

Pompecki, J. F. 1890. Die Trilobiten-fauna der Ost- und Westpreussischen Diluvialgeschiebe. Beitr. Naturk. Preussens, 7.

Rõõmusoks, A. 1953. Novye dannye o trilobitakh roda Chasmops iz ordovika Éstonskoj SSR. In Loodusuurijate Seltsi juubelikoguteos, 1853-1953, pp. 396-413. Tallinn (in Russian).

Rõõmusoks, A. 1986. Oculichasmops - a new genus of the trilobite subfamily Chasmopinae. Proc. Estonian Acad. Sci. Geol., 35, 156-159 (in Russian).

Rõõmusoks, A. 1991. On the stratigraphy and fauna of the boundary beds between the Pirgu and Porkuni Stages of North Estonia. Acta Comment. Univ. Tartuensis, 934, 23-42 (in Russian).

Rõõmusoks, A. 1997. Ordovician trilobites. In Geology and Mineral Resources of Estonia (Raukas, A. \& Teedumäe, A., eds.), pp. 234-238. Estonian Acad. Publ., Tallinn.

Rõõmusoks, A. 1998. Trilobites of the genus Toxochasmops from the Ordovician of Estonia. Proc. Estonian Acad. Sci. Geol., 47, 173-194.

Schmidt, F. 1881. Revision der ostbaltischen silurischen Trilobiten nebst geognostischer Übersicht des ostbaltischen Silurgebiets. Abt. 1. Phacopiden, Cheiruriden und Encrinuriden. Mem. Acad. Imp. Sci. St.-Petersb., 7e série, $\mathbf{3 0}, 1$.

Schmidt, F. 1907. Revision der ostbaltischen silurischen Trilobiten. Abt. 6. Mem. Acad. Imp. Sci. St.-Petersb., 8e série, 20, 8.

Störmer, L. 1945. Remarks on the Tretaspis (Trinucleus) Shales of Hadeland. Norsk Geol. Tidsskr., 25, 379-426.

Wigand, G. 1888. Ueber die Trilobiten der silurischen Geschiebe in Mecklenburg. Zeitschr. Deutschen Geol. Gesellschaft, XL, 39-101.

Wiman, C. 1901. Über die Borkholmer Schicht im Mittelbaltischen Silurgebiet. Bull. Geol. Inst. Univ. Upsala, V, 149-222. 


\section{UUS TRILOBIIDIPEREKOND VALDARIOPS EESTI HARJU SEERIAST (ÜLEMORDOVIITSIUM)}

\section{Arvo RÕ̃̃MUSOKS}

F. Schmidti (1881) kirjeldatud liik Phacops (Chasmops) eichwaldi omaaegsest Lyckholmi lademest, nüüdse stratigraafilise liigestuse järgi Nabala, Vormsi ja Pirgu lademest, osutus kompleksseks liigiks. Seda liikide gruppi on kirjeldatud uue perekonnana Valdariops, millesse kuuluvad peale revideeritud tüüpliigi $V$. eichwaldi uned liigid V.aliquantulus, V.angustus ja V. kernuensis. Neile lisaks on esitatud fotod veel kahest vormist - Valdariops sp. nov. A ja Valdariops sp. nov. B, mille väikesed eksemplarid on halvasti säilinud. Kõigil nimetatud trilobiitidel on Põhja-Eesti konfatsiaalses vööndis piiratud stratigraafiline levik.

\section{VALDARIOPS - НОВЫЙ РОД ТРИЛОБИТОВ ИЗ ХАРЫЮСКОЙ СЕРИИ ВЕРХНЕГО ОРДОВИКА ЭСТОНИИ}

\section{Арво РЫЫМУСОКС}

Phacops (Chasmops) eichwaldi, описанный Ф. Шмидтом (1881) из прежнего лигкольмского горизонта, т.е. из интервала, охватывающего на современной стратиграфической схеме набалаский, вормсиский и пиргуский горизонты, оказался комплексным видом. Все составляющие его виды описаны здесь в качестве нового рода Valdariops с типовым видом V. eichwaldi. В составе этого рода в качестве новых описаны виды V. aliquantulus, V. angustus и V. kernuensis; дополнительно представлены фотоснимки еще двух форм - Valdariops sp. nov. А и Valdariops sp. nov. В. Распространение всех названных трилобитов стратиграфически ограничено пределами Северо-Эстонской конфациальной зоны Эстонии. 